Marcin Łysko

\title{
Ministerstwo Sprawiedliwości u progu planu 6-letniego - dokument archiwalny
}

\section{Wprowadzenie}

Prezentowany dokument zawiera przemówienie ministra sprawiedliwości Henryka Świątkowskiego wygłoszone w dniu 25 stycznia 1950 r. podczas Posiedzenia Komisji Prawniczej i Regulaminowej Sejmu Ustawodawczego. Przedmiotem obrad Komisji był preliminarz budżetowy Ministerstwa Sprawiedliwości na rok 1950.

Odnosząc się do projektowanego budżetu Ministerstwa Sprawiedliwości, H. Świątkowski omówił najważniejsze kierunki działalności ministerstwa w roku 1949 oraz planowane zadania na rok 1950 w kontekście aktualnej sytuacji politycznej. Po zdemaskowaniu odchylenia prawicowo-nacjonalistycznego w szeregach partii we wrześniu 1948 r. i przejęciu pełni władzy przez posłuszną Moskwie ekipę B. Bieruta rozpoczął się trwający do połowy lat pięćdziesiątych okres polskiego stalinizmu. Cechą charakterystyczną tego okresu było mechaniczne powielanie rozwiązań radzieckich we wszystkich dziedzinach życia państwowego, gospodarczego i społecznego. Cały aparat państwowy, w tym także Ministerstwo Sprawiedliwości, miał brać aktywny udział w procesie budowania podstaw socjalizmu. Procesowi temu towarzyszyła teoria o zaostrzaniu się walki klasowej w miarę postępów budownictwa socjalistycznego. W walkę klasową zaangażowano aparat wymiaru sprawiedliwości, obarczając go zadaniem zwalczania rzeczywistych i wyimaginowanych przeciwników władzy komunistycznej za pomocą przymusu państwowego. Pozostałe zadania wymiaru sprawiedliwości nawiązywały do teorii Stalina o kulturalno-wychowawczej funkcji wymiaru sprawiedliwości wobec osób akceptujących ustrój socjalistyczny. Wymiar sprawiedliwości miał wdrażać te osoby do poszanowania własności socjalistycznej oraz przestrzegania zasad współżycia społecznego za pomocą metod przekony- 
wania. Dopiero gdyby te metody zawiodły, miał być stosowany przymus państwowy ${ }^{1}$.

Za najważniejsze dokonanie Ministerstwa Sprawiedliwości w roku 1949 Świątkowski uznał nowelizację procedury karnej w duchu socjalistycznym ${ }^{2}$. Nowelizacja polegała na przeniesieniu do pochodzącego z $1928 \mathrm{r}$. kodeksu postępowania karnego ${ }^{3}$ zmian cząstkowych, zawartych w dekretach i ustawach prawnokarnych wydanych w latach 1944-1946. Najważniejsze z tych zmian polegały na likwidacji instytucji sędziego śledczego, upoważnieniu oficerów śledczych Ministerstwa Bezpieczeństwa Publicznego do prowadzenia śledztw, podporządkowania całego postępowania przygotowawczego prokuratorowi oraz zniesieniu trójinstancyjności postępowania. W sprawach karnych pierwszej instancji w sądach okręgowych i apelacyjnych jako regułę wprowadzono skład ławniczy, czyli sędzia plus dwóch ławników ${ }^{4}$. Ławnicy czuwali nad realizacją polityki partii komunistycznej w zakresie wymiaru sprawiedliwości i zawsze mogli przegłosować sędziego zawodowego, gdyż posiadali wszelkie uprawnienia sędziowskie $\mathrm{z}$ wyjątkiem przewodniczenia rozprawie.

Do znowelizowanej procedury karnej dostosowano przepisy o postępowaniu doraźnym ${ }^{5}$ oraz strukturę sądów apelacyjnych ${ }^{6}$. Została ona dopasowana do podziału państwa na potrzeby administracji ogólnej, co w praktyce uzależniało sądy apelacyjne od organów władzy i administracji państwowej szczebla wojewódzkiego. W sądach apelacyjnych jako pierwszej instancji skupiono najważniejsze z punktu widzenia ochrony interesów państwa sprawy karne, w tym te sprawy o przestępstwa polityczne, które nie były przekazane do sądownictwa wojskowego ${ }^{7}$.

Ukształtowanie procedury karnej w duchu socjalistycznym wynikało z traktowania prawa karnego jako instrumentu służącego zwalczaniu wroga klasowego i przebudowie struktur społeczno-gospodarczych ${ }^{8}$. Wprowadzanie socjalistycz-

1 L. Chajn, Wymiar sprawiedliwości stoi na straży ustroju ludowo-demokratycznego naszego kraju, „Nowe Prawo" (dalej: NP) 1952, nr 8-9, s. 24-25.

2 Została ona dokonana ustawą z dnia 27 kwietnia 1949 r. o zmianie przepisów postępowania karnego (Dz. U. Nr 32, poz. 238).

${ }_{3}$ Rozporządzenie Prezydenta Rzeczypospolitej Polskiej z 19 marca 1928 r. kodeks postępowania karnego (Dz. U. Nr 33, poz. 243).

${ }^{4}$ A. Lityński, Historia prawa Polski Ludowej, Warszawa 2006, s. 144.

5 Dekret z 16 listopada 1945 r. o postępowaniu doraźnym (Dz. U. Nr 53, poz. 301).

${ }^{6}$ Ustawa z dnia 27 kwietnia 1949 r. o zmianie prawa o ustroju sądów powszechnych (Dz. U. Nr 32, poz. 237).

7 Nowela k.p.k. z 27 kwietnia 1949 r. do sądu apelacyjnego jako I instancji zaliczała: - sprawy o charakterze politycznym, które nie były przekazane do kompetencji sądownictwa wojskowego, $\mathrm{w}$ tym sprawy z dekretu z 22 stycznia o odpowiedzialności za klęskę wrześniową i faszyzacje życia państwowego; - sprawy z tzw. sierpniówki, wykorzystywanej w sfingowanych procesach politycznych; - sprawy gospodarcze, jeżeli ,interesy gospodarcze Polski Ludowej zostały narażone na znaczną szkodę”.

8 A. Lityński, O prawie i sądach początków Polski Ludowej, Białystok 1999, s. 58. 
nych zasad polityki gospodarczej w ramach przewidzianego na lata 1950-1955 planu sześcioletniego, pociągnęło za sobą koncentrację orzecznictwa sądowego na sprawach gospodarczych. Sądy miały surowo karać osoby uznane za „szkodników gospodarczych i sabotażystów", natomiast w zakresie spraw cywilnych chronić interesy popieranych przez państwo spółdzielni produkcyjnych oraz chłopów małorolnych w sporach majątkowych z kułakami. Sądownictwo miało być aktywnie wspierane przez prokuraturę, która zaczęła prowadzić zakrojoną na szeroką skalę działalność profilaktyczną w zakresie zapobiegania przestępczości. Działalność profilaktyczna w połączeniu $\mathrm{z}$ badaniem nieprawidłowości funkcjonowania aparatu państwowego stanowiła zapowiedź późniejszego powierzenia prokuraturze wykonywania tzw. nadzoru ogólnego'. W 1949 r. główny wysiłek prokuratury skupiał się na przeciwdziałaniu szkodnictwu gospodarczemu oraz ściganiu sprawców przestępstw gospodarczych, a o sprawności jej działania miał świadczyć znaczący wzrost liczby wykrytych przestępstw ${ }^{10}$.

Obarczenie sądów i prokuratury zadaniami zwalczania wroga klasowego i aktywnego udziału w procesie budowy socjalistycznego ustroju społeczno-gospodarczego rodziło problem właściwej pod względem politycznym obsady kadrowej wymiaru sprawiedliwości. W 1949 r. resort sprawiedliwości zatrudniał liczną grupę przedwojennych prawników, których przyjęto do pracy w ramach stopniowego uruchamiania kolejnych sądów i prokuratur po zakończeniu działań wojennych. Ludzi tych $\mathrm{z}$ racji udziału w wymiarze sprawiedliwości II Rzeczypospolitej traktowano jako niepewnych klasowo, czyli nienadających się do realizacji zadań stojących przed socjalistycznym sądownictwem. Byli oni stopniowo usuwani z wymiaru sprawiedliwości na podstawie przepisów dekretu z grudnia 1944 r., który umożliwiał swobodne przenoszenie sędziów i prokuratorów w stan spoczynku lub zwolnienie ze służby, a także zmianę grupy uposażenia i stanowiska służbowego ${ }^{11}$. Ponieważ szkolenie prawników w normalnym trybie ze względu na wymóg ukończenia studiów prawniczych i odbycia aplikacji było procesem długotrwałym, to dekretem z 22 stycznia 1946 r. wprowadzono możliwość obejmowania stanowisk sędziowskich i prokuratorskich przez kandydatów nieposiadających wymaganego wykształcenia, lecz sprawdzonych pod względem polityczno-ideowym ${ }^{12}$. Osoby dające „rękojmię właściwego wykonywania obowiązków sędziowskich i prokuratorskich" przyjmowano do pracy

9 Problematyce nadzoru ogólnego poświęcona jest monografia M. Łysko, Prokuratorski nadzór ogólny w Polsce Ludowej w latach 1950-1967, Białystok 2006.

${ }^{10}$ G. Auscaler, O Prokuraturze Rzeczypospolitej Polskiej, „Wojskowy Przegląd Prawniczy” 1950, nr 2, s. 125.

${ }^{11}$ Dekret z 27 grudnia 1944 r. o tymczasowym unormowaniu stosunku służbowego funkcjonariuszów państwowych (Dz. U. Nr 16, poz. 89).

12 Dekret z dnia 22 stycznia 1946 r. o wyjątkowym dopuszczeniu do obejmowania stanowisk sędziowskich, prokuratorskich i notarialnych oraz do wpisywania na listę adwokatów (Dz. U. Nr 4, poz. 33). 
w wymiarze sprawiedliwości po ukończeniu prowadzonych przez Ministerstwo Sprawiedliwości specjalnych szkół prawniczych. Do 1949 r. utworzono 4 średnie szkoły prawnicze: w Łodzi (1946-1952), Wrocławiu (1947-1953), Gdańsku (1947-1948), Toruniu (1948-1952). Kandydaci do szkół prawniczych byli rekomendowani pod względem społeczno-politycznym przez partię rządzącą, organizacje społeczne i związki zawodowe. Oprócz średnich szkół prawniczych funkcjonowała otwarta w 1948 r. Centralna Szkoła Prawnicza im. Teodora Duracza, która była odpowiednikiem wyższych studiów prawniczych ${ }^{13}$. Zatrudnienie pobieżnie wykształconych absolwentów szkół prawniczych odbiło się ujemnie na poziomie pracy wymiaru sprawiedliwości. Wskazuje na to wypowiedź ministra Świątkowskiego, który stwierdził, że „kwalifikacje zawodowe absolwentów szkół prawniczych pozostawiają jeszcze wiele do życzenia", wobec czego powinni być oni poddani dokształcaniu zawodowemu.

Zagadnienie obsady kadrowej i szkolenia ideologiczno-zawodowego minister Świątkowski uznał za podstawowe wyzwanie stojące przed Ministerstwem Sprawiedliwości w 1950 r. Wzmocnieniu kadr sądowo-prokuratorskich nowymi ludźmi służyło zapowiadane otwarcie dwóch nowych średnich szkół prawniczych w Szczecinie (1950-1951) i Zabrzu (1950-1951). Przewidywano także zorganizowanie specjalnych kursów dla ławników celem powierzenia im stanowisk sędziowskich. Rozpoczęcie realizacji planu 6-letniego postawiło przed aparatem sądowo-prokuratorskim zadanie aktywnego wspierania procesu budowy socjalizmu, co wymagało zwiększenia obsady kadrowej ludźmi pewnymi politycznie. Stąd wysuwane przez ministra Świątkowskiego żądanie przyznania środków budżetowych na utworzenie nowych etatów sędziowskich i prokuratorskich. W przypadku prokuratury obsada kadrowa była niedostateczna w stosunku do stawianych zadań, zwłaszcza wykonywania działalności profilaktycznej, ukierunkowanej na zapewnienie sprawnej realizacji planu 6-letniego ${ }^{14}$.

Oprócz kwestii kadrowych w centrum zainteresowania Ministerstwa Sprawiedliwości w 1950 r. znalazły się problemy związane z przebudową prawa sądowego i wymiaru sprawiedliwości w duchu socjalistycznym. Największy nacisk położono na kodyfikację prawa karnego, które $\mathrm{z}$ racji uregulowania w pochodzącym z 1932 r. kodeksie karnym ${ }^{15}$ nie przystawało do warunków społeczno-politycznych Polski Ludowej. Wprawdzie po II wojnie wydano liczne dekrety penalizujące życie polityczne, społeczne i gospodarcze, jednak nie stanowiły one zwartego systemu prawa, wskutek czego występowały poważne luki utrudniające praktykę sądową. Uchwała Prezydium Rządu z 27 września 1950 r. za-

${ }_{13}$ A. Lityński, O prawie i sądach..., s. 139-140.

${ }^{14}$ T. Rek, Reforma i zadania aparatu wymiaru sprawiedliwości na tle Planu Sześcioletniego, NP 1950, nr 10, s. 15.

${ }^{15}$ Rozporządzenie Prezydenta Rzeczypospolitej Polskiej z 11 lipca 1932 r. kodeks karny (Dz. U. Nr 60, poz. 571). 
lecała Ministerstwu Sprawiedliwości przygotowanie projektu kodeku karnego do 1 września 1951 r. ${ }^{16}$ W 1951 r. został opublikowany projekt części ogólnej kodeksu karnego, który spotkał się ze zdecydowaną krytyką doktryny, wskutek czego czynniki oficjalne podjęły decyzje o pozostawieniu projektu bez dalszego biegu $^{17}$.

W dziedzinie prawa cywilnego minister Świątkowski zapowiedział podjęcie prac nad projektem prawa rzeczowego oraz kodyfikację prawa rodzinnego. Po przewrocie politycznym drugiej połowy 1948 r. władze zaczęły głosić pogląd, że prawo cywilne ma być czynnikiem przyspieszającym budowę ustroju socjalistycznego i pod tym kątem wymaga rewizji założeń ideologicznych. $\mathrm{Na}$ wzór radziecki system prawa cywilnego musiał uwzględniać zróżnicowanie form własności i w sposób szczególny chronić własność społeczną, w przeciwieństwie do jedynie tolerowanej przez władze własności indywidualnej i osobistej. Zerwanie z jednolitym pojmowaniem własności znalazło swój wyraz w konstytucji PRL z 1952 r., przesądzając o kształcie podstawowych rozwiązań cywilnoprawnych ${ }^{18}$. Podobnie jak w przypadku prawa karnego, prace nad kodyfikacją prawa cywilnego $\mathrm{w}$ duchu socjalistycznym podjęto jesienią 1950 r. Opierając się na wzorcach i doświadczeniach radzieckich, opublikowano w 1954 r. projekt kodeksu cywilnego, który różnicował formy własności i ich ochronę oraz formułował zasadę jedności własności państwowej. Projekt został poddany krytyce przez środowisko prawnicze, wskutek czego Ministerstwo Sprawiedliwości pozostawiło go bez dalszego biegu. Projekt kodeksu cywilnego z 1954 r. składał się z czterech ksiąg, gdyż na wzór radziecki wyłączono z niego prawo rodzinne i opiekuńcze. Umieszczenie prawa rodzinnego poza ramami systemu prawa cywilnego uzasadniano ideologicznie, głosząc tezę o wyzwoleniu stosunków rodzinnych w ustroju socjalistycznym od znamiennych dla ustrojów burżuazyjnych stosunków majątkowych ${ }^{19}$. Prawo rodzinne Polski Ludowej zgodnie z zapowiedzią ministra Świątkowskiego doczekało się odrębnej kodyfikacji, która była przygotowywana od 1949 r. we współpracy z Czechosłowacją. Kodeks rodzinny z $1950 \mathrm{r}^{20}{ }^{20}$ zawierał przepisy o małżeństwie, o stosunkach między rodzicami a dziećmi, o przysposobieniu oraz o opiece nad małoletnimi. Był to akt prawny stojący na niskim poziomie techniki legislacyjnej, zawierał wiele luk, wypełnianych dopiero później orzecznictwem sądowym ${ }^{21}$. Podstawowe idee kodeksu to świecki charakter instytucji

\footnotetext{
${ }^{16}$ Uchwała Prezydium Rządu dotyczaca prac kodyfikacyjnych, PiP 1950, nr 1, s. 67.

${ }^{17}$ A. Lityński, Historia prawa..., s. 152.

${ }^{18}$ Z. Radwański, Prawo cywilne PRL, „Czasopismo Prawno-Historyczne” (dalej: CPH) 1995, z, 1-2, s. 23-24.

${ }^{19}$ Ibidem, s. 26.

${ }^{20}$ Ustawa z dnia 27 czerwca 1950 r. Kodeks rodzinny (Dz. U. Nr 34, poz. 308).

${ }^{21}$ J. Skąpski, Kodeks cywilny z 1964 r. Blaski i cienie kodyfikacji oraz jej perspektywy, „Kwartalnik Prawa Prywatnego" 1992, z. 1-4, s. 64.
} 
małżeństwa, zasada egalitaryzmu małżonków oraz zasada trwałości związku małżeńskiego. Kodeks dopuszczał wprawdzie rozwód, ale jedynie w przypadku zaistnienia ważnych powodów, w tym zupełnego i trwałego rozkładu pożycia małżeńskiego. W zakresie stosunków majątkowych małżeńskich na wzór radziecki przyjęto ustawowy ustrój wspólności majątkowej²2.

W prezentowanym dokumencie minister Świątkowski zapowiedział dokonanie zmian ustroju sądów powszechnych celem dostosowania ich struktury do podziału administracyjnego państwa. Odmienność podziału administracyjnego i sądowego z czasów II Rzeczypospolitej miała na celu uniezależnienie sądów od władz administracyjnych. W Polsce Ludowej głoszono hasło o potrzebie ścisłego powiązania pracy sądów z pracą innych organów państwowych, choć w rzeczywistości chodziło o poddanie sądownictwa kontroli władzy politycznej i państwowej. W marcu 1950 r. zlikwidowano urzędy wojewodów i starostów, przekazując ich kompetencje radom narodowym, które pełniły funkcje terenowych organów władzy i administracji państwowej ${ }^{23}$. Kompleksowa reforma sądownictwa została przeprowadzona ustawą z 20 lipca $1950 \mathrm{r}^{24} \mathrm{~W}$ jej wyniku wprowadzono dostosowany do podziału administracyjnego kraju na powiaty i województwa system sądów powszechnych. W miejsce dotychczasowych sądów grodzkich, okręgowych i apelacyjnych funkcjonowały sądy powiatowe i wojewódzkie, najwyższą instancją pozostał Sąd Najwyższy. Utworzenie nowej struktury sądów łączyło się ze zmianami postępowania sądowego. Postępowanie sądowe było dwuinstancyjne, orzeczenia sądów pierwszej instancji kwestionowano za pomocą rewizji, przy czym Sąd Najwyższy rozpatrywał rewizje od wyroków sądów wojewódzkich. Do wzruszania prawomocnych wyroków służyła rewizja nadzwyczajna, jednak prawo jej wniesienia do Sądu Najwyższego nie przysługiwało skazanemu, lecz prokuratorowi generalnemu. Sąd Najwyższy uzyskał prawo wydawania wiążących wytycznych wymiaru sprawiedliwości i praktyki sądowej, czyli decydowania o kształcie orzecznictwa sądowego. Socjalistyczny obraz polskiego sądownictwa po reformie lipca 1950 r. dopełniało uznanie zasady składu ławniczego sądów pierwszej instancji w sprawach karnych i cywilnych, połączone z unormowaniem sytuacji procesowej i obowiązków ławników ${ }^{25}$.

Wraz z reformą struktury sądownictwa wprowadzono radziecki model prokuratury $^{26}$, która została całkowicie wyodrębniona $\mathrm{z}$ resortu sprawiedliwości w odrębny pion organów państwowych. Rozdzielono funkcje ministra sprawiedliwości i prokuratora generalnego. Generalny prokurator był powoływany przez

\footnotetext{
${ }^{22}$ S. Szer, Kodeks rodzinny, „Demokratyczny Przegląd Prawniczy” 1950, z. 3, s. 10-11.

${ }^{23}$ Ustawa z dnia 20 marca 1950 r. o terenowych organach jednolitej władzy państwowej (Dz. U. Nr 14, poz. 130.)

${ }^{24}$ Ustawa z 20 lipca 1950 r. o zmianie prawa o ustroju sądów powszechnych (Dz. U. Nr 38, poz. 347).

${ }^{25}$ R. Walczak, Polityka, sady, prokuratura, Warszawa 1990, s. 71.

${ }^{26}$ Ustawa z 20 lipca 1950 r. o Prokuraturze Rzeczypospolitej Polskiej (Dz. U. Nr 38, poz.346).
} 
Radę Państwa, jego organami byli prokuratorzy wojewódzcy i powiatowi. Kompetencje prokuratury określono na wzór radziecki, jej podstawowym zdaniem była ogólna kontrola przestrzegania prawa, której zakres wykraczał poza tradycyjne ściganie przestępstw i oskarżanie przed sądem. Prokuratura wykonywała powszechną kontrolę zgodności z prawem działalności terenowych organów władzy i administracji państwowej, instytucji gospodarczych oraz przestrzegania prawa przez poszczególnych obywateli. Uprawnienie to określano jako nadzór ogólny. Ponadto prokuratura otrzymała bardzo szerokie kompetencje w postępowaniu cywilnym ${ }^{27}$.

W 1950 r. przeprowadzono zasadnicze zmiany w ustroju adwokatury, opierając się na przygotowanym przez Ministerstwo Sprawiedliwości projekcie ustawy. Zdaniem ministra Świątkowskiego projekt został opracowany „zgodnie z nowymi, socjalistycznymi założeniami naszego prawa" i miał na celu zastąpienie rozwiązań przedwojennych, w świetle których adwokatura zorganizowana była na zasadzie samorządu zawodowego. Ustawa z 27 czerwca 1950 r. o ustroju adwokatur ${ }^{28}$ wprowadzała instytucję zespołów adwokackich jako wyższej, uspołecznionej i kolektywnej formy wykonywania zawodu. Organizacja terytorialna adwokatury została przystosowana do nowego podziału administracyjnego i sądowego, w poszczególnych województwach funkcjonowały izby adwokackie. Adwokaturę poddano drobiazgowemu nadzorowi ministra sprawiedliwości, co $\mathrm{w}$ połączeniu z naciskami politycznymi w praktyce wykluczało funkcjonowanie samorządu adwokackiego aż do 1956 r. ${ }^{29}$

W prezentowanym dokumencie minister Świątkowski zapowiedział przeprowadzenie w $1950 \mathrm{r}$. prac nad projektem ustawy o notariacie. Zmiana statusu prawnego notariuszy została dokonana ustawą z 25 maja 1951 r. $^{30}$, która wzorem radzieckim tworzyła państwowe biura notarialne. Notariuszy powoływał, przenosił i odwoływał minister sprawiedliwości. On tez sprawował zwierzchni nadzór nad działalnością państwowych biur notarialnych ${ }^{31}$.

Dokonane w roku 1949 w oparciu o projekty Ministerstwa Sprawiedliwości zmiany postępowania karnego i organizacji sądów powszechnych stanowiły preludium do przeprowadzenia zasadniczej reformy systemowej w duchu socjalistycznym. Reforma z lipca 1950 r. ostatecznie przesądziła o kształcie prawa sądowego i ustroju organów wymiaru sprawiedliwości Polski Ludowej, gdyż przeprowadzane po 1956 r. zmiany nie naruszały podstawowych zasad systemu. Dopiero przełom roku 1989 zapoczątkował proces stopniowej przebudowy prawa sądowego i ustroju organów wymiaru sprawiedliwości w kierunku zbli-

\footnotetext{
${ }^{27}$ M. Łysko, Prokuratorski nadzór ogólny w Polsce w latach 1950-1967, CPH 2005, z. 2, s. 205.

${ }^{28}$ Dz. U. Nr 30, poz. 275.

${ }^{29}$ A. Lityński, Historia prawa..., s. 101.

${ }^{30}$ Ustawa z dnia 25 maja 1951 r. Prawo o notariacie (Dz. U. Nr 36, poz. 276).

${ }^{31}$ A. Lityński, Historia prawa..., s. 107.
} 
żonym do rozwiązań obowiązujących w II Rzeczypospolitej, czyli powrotu do stanu prawnego sprzed reformy lat 1949-1950. Proces ten do dnia dzisiejszego nie został zakończony, stąd $\mathrm{w}$ warunkach demokratycznego państwa prawnego funkcjonują niektóre rozwiązania prawne rodem z epoki stalinowskiej, których ostateczna likwidacja stanowi wyzwanie stojące zarówno przed nauką prawa, jak też władzami państwa polskiego.

\section{DOKUMENT}

1950 styczeń 25, Warszawa. - Wystąienie ministra sprawiedliwości Henryka Światkowskiego na posiedzeniu Komisji Prawniczej i Regulaminowej

Sejmu Ustawodawczego.

SEJM USTAWODAWCZY RZECZYPOSPOLITEJ POLSKIEJ

Sesja jesienna 1949/1950

\section{DIARIUSZ}

z posiedzenia Komisji Prawniczej i Regulaminowej

obradującej nad preliminarzem budżetowym Ministerstwa Sprawiedliwości

/cz. 10/

Posiedzenie z dnia 25.I.1950 r. godz.10.

Porządek dzienny:

Sprawozdanie o cz. 10 - Ministerstwa Sprawiedliwości preliminarza budżetowego na rok 1950

- sprawozdawca poseł Leszek Guzicki.

Przewodniczący - Wicemarszałek Wacław Barcikowski

Referent - Minister Sprawiedliwości Dr Świątkowski

Koreferent - poseł Guzicki /SD/.

Obecni: - Minister Sprawiedliwości - ob. Henryk Świątkwski, Wiceminister Sprawiedliwości, Tadeusz Rek, oraz inni przedstawiciele Ministerstwa Sprawiedliwości, przedstawiciele Ministerstwa Skarbu i Najwyższej Izby Kontroli. 
$\mathrm{KP} / \mathrm{I} / 2$

Otwierając posiedzenie Przewodniczący Komisji Wicemarszałek Barcikowski udzielił głosu Ministrowi Sprawiedliwości Ob. Henrykowi Świątkowskiemu.

Minister Świątkowski przystępując do objaśnienia budżetu Ministerstwa Sprawiedliwości zaznaczył, że punktem wyjścia dla zobrazowania działalności Ministerstwa Sprawiedliwości w roku 1949, oraz dla wytyczenia linii polityki i działalności Ministerstwa w roku 1950 jest nakreślenie podstawowych zadań i zamierzeń jakie stoją przed aparatem wymiaru sprawiedliwości w Polsce Ludowej w okresie budowania zrębów socjalizmu.

Zadania te kształtują się na gruncie konkretnej sytuacji, na froncie walki klasowej. Leżą one w płaszczyźnie tych zadań jakie stoją przed całym aparatem gospodarczym, politycznym i państwowym w dziele budowania podstaw socjalizmu.

Zadania sądów i prokuratury rozrastają się wraz ze wzmożeniem walki klasowej. W związku z tym, zadaniem aparatu wymiaru sprawiedliwości jest tłumienie działalności wroga klasowego, tłumienie siłą przymusu państwowego. Wraz z przechodzeniem przez elementy wrogie klasowo do form walki zamaskowanych i podstępnych, zadania stojące przed aparatem sądowym stają się coraz trudniejsze. Do tego potrzebna jest umiejętność rozpoznawania wroga klasowego, umiejętność dostrzegania podłoża klasowego każdej działalności przestępczej.

Ważnymi funkcjami aparatu wymiaru sprawiedliwości w Polsce są funkcje gospodarczo-organizacyjne i kulturalno-wychowawcze. Te ostatnie dotyczą wychowania mas ludowych w duchu poszanowania własności socjalistycznej, oraz poszanowania reguł współżycia socjalistycznego.

Omówienie planu pracy na rok 1950, oraz sprawozdanie za rok ubiegły naświetlone będą z punktu widzenia wymienionych założeń.

Rok 1949 - to rok dostosowania aparatu wymiaru sprawiedliwości do roli jaką mu wyznaczyła wzmożona walka klasowa, to rok obfitujący w wysiłki na odcinku ustawodawczym, na odcinku nadzorowania pracy całego aparatu oraz wysiłków w dziedzinie szkolenia kadr sądowo-prokuratorskich.

$\mathrm{KP} / \mathrm{I} / 3$

$$
-3-
$$

W dziedzinie ustawodawstwa opracowano: projekt prawa rodzinnego, projekt przepisów o postępowaniu niespornym dotyczącym stosunków między rodzicami a dziećmi oraz opieki i kurateli, projekt ustawy o ustroju adwokatury. Te trzy akty ustawodawcze zostały opracowane zgodnie z nowymi, socjalistycznymi założeniami naszego prawa.

Do najpoważniejszych osiągnięć należy nowelizacja procedury karnej, nowelizacja przepisów o postępowaniu doraźnym oraz zmiany dokonane w prawie o ustroju sądów powszechnych, uchwalone przez Sejm w ubiegłym roku. 
Znaczenie tych reform jest doniosłe ze względu na dostosowanie struktury sądów apelacyjnych do ogólnego podziału administracyjnego Państwa - co przyczynia się do pogłębienia współpracy organów sądowych z Radami Narodowymi i władzami administracji ogólnej. Dalszym następstwem przeprowadzonej reformy jest możność skupienia uwagi na najbardziej groźnych przestępstwach /sprawy gospodarcze/, które przekazano w I instancji sądom apelacyjnym. Dzięki reformie zwiększył się udział czynnika obywatelskiego przez powiększenie liczby ławników. Wzmiankowana reforma wzmocniła także pozycję sądownictwa dla nieletnich /wydziały dla nieletnich w og. aparacie sprawiedliwości/.

Zmiana procedury karnej wpłynęła na ulepszenie pracy prokuratury. Prokuratura winna być czynnikiem bojowym, sięgającym do wydarzeń odbywających się w terenie. Winna sama analizować źródła i przyczyny przestępczości oraz pomagać aparatowi politycznemu i gospodarczemu w zwalczaniu niedomagań rodzących z kolei przestępstwa. Główny wysiłek prokuratury skupiał się w roku ubiegłym na dziedzinie szkodnictwa gospodarczego. W tym celu prokuratura wiąże się coraz silniej z organami Bezpieczeństwa Publicznego, Milicji Obywatelskiej, z Komisją Specjalną i Radami Narodowymi.

Wzrasta sprawność prokuratury, co najlepiej ilustruje cyfra zawieszeń spraw z powodu niewykrycia przestępstwa, która w porównaniu z rokiem ubiegłym zmalała o 34\%. Znaczy to, że prokuratura staje się świadomym, bojowym narzędziem władzy ludowej.

$\mathrm{KP} / \mathrm{I} / 4$

$-4-$

Sądy przenoszą punkt ciężkości na sprawy karne /dotyczy to działalności w roku 1949/. Stanowią one w sądach apelacyjnych 78\%, w okręgowych $61 \%$ ogólnej ilości spraw. Zjawisko to występuje w związku z zaostrzeniem form walki klasowej.

W sprawach cywilnych występuje także zjawisko walki klas. Dotyczy to spraw związanych z rozwojem spółdzielni produkcyjnych, spraw które ilustrują konflikt pomiędzy bogaczem wiejskim a biedotą.

Polityka kryminalna sądów ukazuje tendencje do surowych represji karnych, w stosunku do szkodników gospodarczych i sabotażystów.

Rok 1949 ilustruje zwiększenie uwagi w dziedzinie walki z przestępczością nieletnich. Zorganizowano na podstawie reformy procedury karnej 34 wydziały sądów okręgowych dla nieletnich, zagadnienie to jest nadal problemem trudnym, gdyż brak jest zakładów poprawczych i niewystarczająca jest sieć kuratorów.

Szczególnie trudne jest zagadnienie postawy politycznej i uświadomienie kadr sądowo-prokuratorskich. W resorcie wymiaru sprawiedliwości istnieje wielu ludzi z przedwojennego aparatu. Na liczbę 3.142 sędziów i prokuratorów, zatrudnionych jest w aparacie sądowo-administracyjnym 1.378 osób ze starej kadry. Liczby te mają 
głęboką wymowę gdyż pracownicy przedwojenni brali udział w aparacie ucisku klasowego i nie mogą spełniać zadań stojących dzisiaj przed polskim sądownictwem.

W celu rozwiązania tego problemu Ministerstwo Sprawiedliwości stopniowo usuwa ludzi /nieodpowiednich z kadr przedwojennych/.

W ostatnim roku usunięto około 100 osób. Sprawy tej nie traktuje się jednak zbyt pochopnie, a raczej rozpatruje się ją na gruncie ścisłej indywidualizacji w stosunku do zainteresowanych osób.

$\mathrm{KP} / \mathrm{I} / 5$

$-5-$

Drugim środkiem zaradczym jest dopływ absolwentów do szkół prawniczych Ministerstwa Sprawiedliwości. Jest to element robotniczo-chłopski. W aparacie wymiaru sprawiedliwości pracuje już 315 absolwentów szkół prawniczych.

Jak widać więc zagadnienie szkolenia kadr wymiary sprawiedliwości jest ogromnie doniosłe.

W związku z tym w roku 1949 ukończyło szkoły prawnicze 127 osób, obecnie w 3-ch szkołach prawniczych kształci się 326 osób. Na kursach zawodowych i ideologicznych przeszkolono 52 aplikantów sądowych.

Szczególnie ważne zadania spełnia Centralna Szkoła Prawnicza im. Tadeusza Duracza w Warszawie. Jej dwuletni program 3-ch lat studiów akademickich. Liczy ona 136 słuchaczów. Praca szkoły wskazuje na to, że poziom jej nie ustępuje poziomowi uniwersyteckich wydziałów prawa.

Oprócz tego Ministerstwo Sprawiedliwości prowadziło w roku 1949 akcję szkolenia ideologicznego pracowników wymiaru sprawiedliwości. Szkolenie to objęło 843 sędziów, prokuratorów, asesorów i aplikantów. Zorganizowano też kurs dla sędziów dla nieletnich i kursy śledztwa. Poza tym odbył się 4-o miesięczny kurs zawodowo-ideologiczny dla aplikantów.

Wszystkie te kursy rozbudziły ogromne zainteresowanie marksizmem-leni nizmem, ale posiadały brak polegający na odrywaniu słuchaczy od pracy zawodowej.

W następstwie tych braków zorganizowano w roku 1949 szkolenie ideologiczne w terenie, obliczone na 8 miesięcy, a obejmujące w swym całokształcie 3 kursy /I - go stopnia dla urzędników, II - go dla sędziów, prokuratorów, asesorów i aplikantów/.

$\mathrm{KP} / \mathrm{I} / 6$

$-6-$

Terenowy kurs prowadzony jest w 10-ciu grupach szkoleniowych i obejmuje przeważający procent sędziów, prokuratorów itd. Jego program to wykład zasad marksizmu-leninizmu, z uwzględnieniem nauki o państwie i prawie. 
Ministerstwo Sprawiedliwości przystąpiło do wydawania przekładów radzieckiej literatury prawniczej, oraz dzieł naszych prawników z dziedziny istoty państwa i wymiaru sprawiedliwości.

Reasumując, zagadnieniem naczelnym, dotyczącym aparatu wymiaru sprawiedliwości, jest zagadnienie napływu nowych kadr oraz problem podniesienia poziomu ideologicznego i zawodowego zatrudnionych już pracowników.

Na rok 1950 szczególnie doniosłe zadania wyłaniają się w dziedzinie ustawodawczej.

Na plan pierwszy wysuwa się praca nad skodyfikowaniem przepisów prawa karnego. Istniejący dotąd kodeks karny z 1932 r. wymaga całkowitej zmiany; istnieją też poważne luki w prawie karnym utrudniające praktykę sądową. Koniecznością jest dostosowanie nowego kodeksu karnego do potrzeb kształtujących się na obecnym etapie rozwoju walki klas.

Zadaniem drugim jest zmiana prawa o ustroju sądów powszechnych w celu włączenia struktury sądowej w system rad narodowych i dostosowania struktury sądowej do podziału administracyjnego państwa.

W roku 1950 przeprowadzi się prace nad projektami ustaw o notariacie. Prace nad projektem prawa cywilnego majątkowego i dalsza kodyfikacja prawa rodzinnego, to dalsze punkty prac przewidzianych na rok 1950.

$\mathrm{KP} / \mathrm{I} / 7$

$$
-7-
$$

Zadania prokuratury na rok 1950 - to wzmożenie akcji profilaktycznej, podniesienie poziomu śledztwa, zaostrzenie walki ze szkodnictwem gospodarczym. Tą akcję utrudnia brak etatów, specjalnie ostry na odcinku prokuratury.

W roku 1950 powstają nowe wymagania pod adresem sądów, w zakresie spraw karnych i cywilnych. Sędzia powinien być świadomym strażnikiem interesów klasowych ludności. Tu także zarysowuje się problem etatów, ze względu na 400 stanowisk sędziowskich nie obsadzonych dotąd, a to dlatego, że nie można przy obecnych wymaganiach natury politycznej znaleźć odpowiednich kandydatów. Sprawa ta jest specjalnie trudna, gdyż w związku z planem 6-letnim wzrosną zadania sądów.

Ze względu na powyższe zagadnienie, Ministerstwo Sprawiedliwości zmuszone będzie wystąpić o powiększenie liczby etatów sędziów i prokuratorów, dla wykonania zwiększonych zadań.

W obecnym roku zwróci się też większą uwagę na zagadnienie przestępczości nieletnich. Znalazło to odbicie w budżecie, w zwiększeniu etatów pracowników zakładów poprawczych.

Zagadnieniem jednak najważniejszym jest sprawa wzmacniania kadr sądowo-prokuratorskich i zapewnienie im dopływu nowych ludzi. Wypływa stąd konieczność uruchomienia dalszych szkół prawniczych. Program tych szkół będzie skrócony, upraktyczniony i połączony z odbywaniem aplikacji. 
Przewiduje się również kursy dla ławników, którzy będą mogli objąć stanowiska sędziowskie, przewiduje się także przyjęcie do prokuratury wyrobionych politycznie i intelektualnie robotników i chłopów /w odpowiedniej ilości/.

Rok 1950 przyniesie wzmożenie akcji szkolenia ideologicznego. Planuje się zorganizowanie kursów szkolenia /korespondencyjnego/, któreby dało

$\mathrm{KP} / \mathrm{I} / 8$

$$
-8-
$$

całość zagadnień państwa i prawa w ujęciu marksistowskim.

Do realizacji tych zadań konieczne są skrypty i podręczniki. Dziedziną tą zajmuje się Komisja Konsultacyjno-Naukowa, która oddała do druku skrypt części ogólnej prawa karnego.

Należy zaznaczyć, że bardzo istotnym zagadnieniem jest sprawa dokształcania zawodowego młodego narybku prawniczego, szkolonego w szybkim tempie. Okazało się bowiem, że kwalifikacje zawodowe absolwentów szkół prawniczych pozostawiają jeszcze dużo do życzenia.

Zagadnienia te odbijają się w zamierzeniach wydawniczych Ministerstwa Sprawiedliwości. W roku 1950 wydane zostaną przekłady podręczników radzieckich z dziedziny prawa karnego i cywilnego, co przyczyni się do poznania teorii i praktyki prawa w świetle zasad marksizmu.

Podstawowym założeniem zamierzeń budżetowych na rok 1950 - kończy Obywatel Minister Świątkowski - jest takie zorganizowanie pracy sądowo-prokuratorskiej by najskuteczniej sprzyjała ona realizacji planu 6-letniego, by nabrała socjalistycznej treści. Aparat zaś sądownictwa i prokuratury jest przepojony świadomością ideologiczną, klasową.

W zakończeniu Ob. Minister stwierdza, iż Ministerstwo Sprawiedliwości dołoży wszelkich starań, by sądownictwo i prokuratury wypełniły swe zadania w dziele budowania podstaw socjalizmu, w dziele realizacji planu 6-letniego.

Oryginał, maszynopis.

Biblioteka Sejmowa w Warszawie, Biuletyn Komisji Wymiaru Sprawiedliwości Sejmu Ustawodawczego, s. 211-215. Pisownia oryginalna. 